\title{
Nanoparticles for Control of Biofilms of Acinetobacter Species
}

\author{
Richa Singh ${ }^{1}$, Shradhda Nadhe ${ }^{1}$, Sweety Wadhwani ${ }^{1}$, Utkarsha Shedbalkar ${ }^{2}$ \\ and Balu Ananda Chopade 1,3,* \\ 1 Department of Microbiology, Savitribai Phule Pune University, Pune 411007, India; \\ richasngh316@gmail.com (R.S.); nshraddha23@gmail.com (S.N.); sweety.wadhwani123@gmail.com (S.W.) \\ 2 Department of Biochemistry, The Institute of Science, Mumbai 400032, India; \\ utkarsha.shedbalkar@gmail.com \\ 3 Dr. Babasaheb Ambedkar Marathwada University, Aurangabad 431004, India \\ * Correspondence: bachopade@gmail.com or vc@bamu.ac.in; Tel.: +91-240-240-3111 \\ Academic Editor: Hideyuki Kanematsu \\ Received: 13 March 2016; Accepted: 10 May 2016; Published: 18 May 2016
}

\begin{abstract}
Biofilms are the cause of $80 \%$ of microbial infections. Acinetobacter species have emerged as multi- and pan-drug-resistant bacteria and pose a great threat to human health. These act as nosocomial pathogens and form excellent biofilms, both on biotic and abiotic surfaces, leading to severe infections and diseases. Various methods have been developed for treatment and control of Acinetobacter biofilm including photodynamic therapy, radioimmunotherapy, prophylactic vaccines and antimicrobial peptides. Nanotechnology, in the present scenario, offers a promising alternative. Nanomaterials possess unique properties, and multiple bactericidal mechanisms render them more effective than conventional drugs. This review intends to provide an overview of Acinetobacter biofilm and the significant role of various nanoparticles as anti-biofouling agents, surface-coating materials and drug-delivery vehicles for biofilm control and treatment of Acinetobacter infections.
\end{abstract}

Keywords: Acinetobacter; biofilm; drug resistance; nanoparticles; phage; anti-biofilm agent

\section{Introduction}

A biofilm is a community of single or mixed bacterial cells adhered to abiotic or biotic surfaces [1]. The biofilm is arranged in a tertiary structure where the bacteria are in intimate contact with each other and encased in a matrix of extracellular polymeric substances (EPS), which can comprise exopolysaccharides, nucleic acids, proteins and other macromolecules [2,3]. The main reasons behind bacterial biofilm formation are: (a) normal mode of growth for some species; (b) protection from adverse host environment; (c) preferential colonization in nutrient-rich conditions; and (d) co-operative benefits as a part of community [4,5]. Ubiquitous in nature, biofilms are found on rocks and pebbles in rivers, surfaces of stagnant water, showers, sewage and drinking-water pipes, marine engineering systems, ship hulls, etc. [6,7]. However, microbial colonization on living tissues, such as heart valves, tooth enamel, lung and middle ear, wounds, medical devices and tissue engineering-related products [5] is a matter of great concern for human health. These medical biofilms are responsible for $65 \%$ to $80 \%$ of clinical infections, which may lead to morbidity and mortality [8,9]. Bacterial cells present in these biofilms express phenotypes, different from planktonic counterparts, and exhibit higher resistance to conventional drugs, ultraviolet light, desiccation, extreme $\mathrm{pH}$ and host's immune defense system [10-13]. Such biofilms have been reported in both Gram-positive and Gram-negative bacteria, including Acinetobacter baumannii, Pseudomonas aeruginosa, Xanthomonas campestris, Staphylococcus aureus, Staphylococcus epidermidis, etc. [14-20]. 


\subsection{Acinetobacter: A Nosocomial Biofilm-Producing Pathogen}

The genus Acinetobacter consists of 34 species, which are non-motile, aerobic and Gram-negative coccobacilli [21]. The bacteria are widely distributed in soil, activated sludge, water, food and human skin [22-29]. The bacteria can survive under highly desiccated conditions on abiotic surfaces for a long time [30,31]. In recent years, they have emerged as the most important nosocomial pathogens implicated in a variety of nosocomial infections, such as urinary and respiratory tract infections, skin and soft-tissue infections, bloodstream infections and secondary meningitis [32-35]. The treatment of Acinetobacter infections is becoming a challenge since these species are rapidly developing resistance to commonly used traditional antibiotics. A. baumannii has been listed as one of the ESKAPE pathogens (Enterococcus faecium, Staphylococcus aureus, Klebsiella pneumoniae, Acinetobacter baumannii, Pseudomonas aeruginosa, and Enterobacter species) owing to the ability to escape the biocidal activity of antibiotics [30]. They have also evolved as one of the most antibiotic and metal-resistant microorganisms [24,31]. The terms like multi-drug resistant (MDR), extensively-drug resistant (XDR) and pan-drug resistant (PDR) are used to describe the level of antibiotic insusceptibility in Acinetobacter spp. MDR Acinetobacter spp. are resistant to at least three classes of antibiotics: all penicillins and cephalosporins, aminoglycosides and fluroquinolones. XDR species are MDR plus carbapenem-resistant, whereas PDR species exhibit resistance to antimicrobials mentioned above along with polymyxins and tigecycline [36-38].

The problem is aggravated due to their colonization and biofilm-forming capacity on medical devices, such as implants, cardiac valves, artificial joints, catheters, etc. [32,39]. Acinetobacter biofilms have also been associated with hospital-acquired infections, chronic non-healing injury-and burn-wound infections, ulcers and battle casualties among military personnel [40,41]. Biofilms cause severe illness and diseases in immuno-compromised patients, especially in case of urinary and respiratory tract infections, ocular infection, otitis media, endocarditis, pneumonia, septicemia, bacteremia, and necrotizing fasciitis, etc. [29,42-44]. There is a correlation between antibiotic resistance and the ability of Acinetobacter to adhere to the clinically relevant surfaces, such as polystyrene and human epithelial cells [45]. Such pathogenic biofilms are heterogeneous and express up to 1000-fold drug resistance, making them difficult to eradicate [46,47]. Resistance exhibited by Acinetobacter biofilms can be natural, genetically acquired or adaptive to survive in that environment $[3,48,49]$. Although the mechanism underlying biofilm resistance is still not completely understood, it may involve the combination of factors shown in Figure 1.

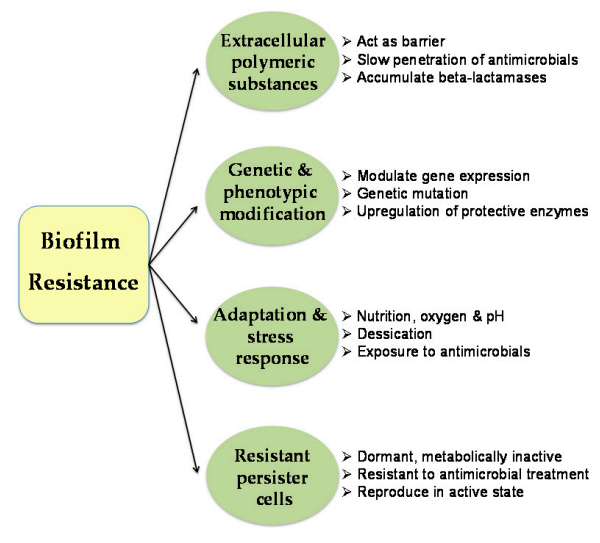

Figure 1. Mechanisms and factors involved in conferring drug resistance in pathogenic biofilms.

\subsection{Treatment Therapies for Control of Acinetobacter Biofilm}

Molecular mechanism of biofilm formation in Acinetobacter needs to be understood to formulate anti-biofouling therapies. The common factors influencing biofilm formation are type of surface, nutrient availability, bacterial surface components like EPS, bacterial appendages including pili and flagella, quorum-sensing communication and extracellular organic secretions [50]. EPS of Gram-negative bacteria is anionic in nature due to uronic acids and ketal-linked pyruvates [51]. 
In such EPS, divalent cations, such as calcium and magnesium, facilitate crosslinking between polymeric polysaccharide strands, thereby increasing viscosity and binding forces in biofilm [51]. Quorum-sensing molecules ( $N$-acyl-L-homoserine lactones, 4-quinolines) are involved in cell density-dependent intercellular communications and regulation of expression of virulence genes for exoenzymes, EPS and stress resistance [52]. Expression of genes, such as blaPER-1 and algC, adhesion proteins and extracellular DNA is critical for cell adhesion, colonization and formation of biofilms [16,45,53-55]. Moreover, biofilm-specific housekeeping, transporter and regulatory proteins [39] can be the ideal targets for developing novel artillery to eradicate colonization and overcome biofilm resistance. Additionally, environmental and physiological factors (nutrient and oxygen availability, concentration of D-amino acids, iron, nitric oxide concentration), cell-cell communication signals (diffusible fatty acids, auto-inducing peptides) and intracellular messengers (c-di-GMP, cAMP) are a few of the molecular triggers, involved in the induction of transition from sessile phenotype to free dispersal phenotype, which can be activated to degrade the biofilms [3,20,56-60].

Prophylactic vaccines, antimicrobial peptides, photodynamic therapy and radioimmunotherapy are control measures employed to prevent and eradicate Acinetobacter biofilms [61-63]. Vaccination with A. baumannii biofilm-associated protein (Bap) and outer membrane porin (OmpA) enhances antigen-specific titers and reduces bacterial loads in intraperitoneal infection model $[63,64]$. Passive immunization with antibodies against membrane polysaccharides and outer membrane transporter has also been shown to elicit in vitro opsonophagocytolysis of A. baumannii $[65,66]$. Several peptides and their analogs, such as brevinin-2-related peptide, cationic alpha-helical skin-derived peptides and alyteserin-2a, showed excellent potency as membrane and cell disruptors against MDR and PDR strains of Acinetobacter [67-69]. Synthetic peptides and analogs can also be designed to develop novel bactericidal agents; however, they have a short life and are prone to proteolytic degradation in vivo.

Photodynamic therapy (PDT) is based on generation of reactive oxygen species (ROS), through photoreactive dyes, which react with target cells to damage the DNA or cellular membranes and organelles [70,71]. Owing to DNA repair machinery, major bactericidal effect of PDT is exerted due to the destruction of structural and transporter proteins and leakage of cellular contents [70]. The limitations of this therapy are restricted topical application and damage to host cells by ROS [71]. Materials, like catheters and implants, can be impregnated with antibiotics that are either embedded in the surface or designed to diffuse out [72]. This will ensure local antibiotic delivery, sustained drug release and lower systemic toxicity risks [72]. Polymers, modified dendrimer and cyclodextrin complexes and microemulsion formulations of antimicrobials are shown to be effective against bacterial and fungal biofilms [73-76]. In recent years, nanomaterials have gained significant importance in diagnosis, medicine and therapeutics as antimicrobials, antitubercular, anticancer and antidiabetic agents, antioxidants, catalysts and sensors [77-84]. Nanoparticles, with any one dimension up to $100 \mathrm{~nm}$, exhibit unique physical, chemical and biological properties due to small size and possess high surface area-to-volume ratio as compared to bulk counterparts $[80,81]$. These characteristics render them highly effective in biological applications and make them potential candidates for development of novel nano-antibiotics. This review is intended to provide an overview of the approach on the control of Acinetobacter biofilms employing various types of nanoparticles, their benefits and limitations. It is also important to recognize the missing links in literature, which should be pursued further for in-depth understanding and applicability of nanoparticles.

\section{Acinetobacter Biofilm Control through Nanomaterials}

Both organic and inorganic nanoparticles are reported to have antibacterial and anti-biofilm potencies [14,85-89]. These are also used as surface-coating and drug-delivery agents $[90,91]$ and thus offer a very promising alternative to conventional methods of biofilm control. Table 1 summarizes the various nanomaterials employed for treatment of Acinetobacter biofilms and infections. It is important to note that in vivo testing of nanoparticles has only been pursued with planktonic Acinetobacter [86,92,93]. Such nanoparticles, in higher concentration, may show biofilm-disruption activity. 
Table 1. Nanomaterials in control of Acinetobacter biofilms and infections.

\begin{tabular}{|c|c|c|c|c|c|c|}
\hline NPs & Composition and Surface Property & Size $(\mathrm{nm})$ & Acinetobacter Strain & Applied Dosage of NPs & Remarks & Ref. \\
\hline \multicolumn{7}{|c|}{ Lipid-based NPs } \\
\hline Lipidic nanocapsules & $\begin{array}{l}\text { (1) carvacol, eugenol and } \\
\text { cinnamaldehyde }(0.96 \% \mathrm{w} / \mathrm{w}) \\
(2) \text { carvacol }(0.34 \% \mathrm{w} / \mathrm{w}) \text {, eugenol } \\
(1.83 \% \mathrm{w} / \mathrm{w}), \text { cinnamaldehyde } \\
(0.39 \% \mathrm{w} / \mathrm{w}) \text { and } \beta \text {-caryophyllene } \\
(0.32 \% \mathrm{w} / \mathrm{w})\end{array}$ & $\begin{array}{l}85-95 \\
62-70\end{array}$ & A. baumannii & $40 \mathrm{mg} / \mathrm{kg}$ & Increased survival in sepsis murine model & [86] \\
\hline $\begin{array}{l}\text { Nanoemulsion } \\
\text { of CPC }\end{array}$ & $\begin{array}{l}\text { CPC }(1 \% \mathrm{w} / \mathrm{v}) \text {, triton X-100 (10\% } \\
\mathrm{v} / \mathrm{v}) \text { and soyabean oil }(25 \% \mathrm{v} / \mathrm{v})\end{array}$ & 213.9 & $\begin{array}{l}\text { A. baumannii ATCC } \\
\text { BAA-1605 }\end{array}$ & $\sim 5-25 \mu \mathrm{g} / \mathrm{mL}$ CPC & $\begin{array}{l}\text { Loss in metabolic activity; complete } \\
\text { biofilm disruption }\end{array}$ & [90] \\
\hline \multicolumn{7}{|c|}{ Polymer-based NPs } \\
\hline Chitosan NPs & OMP loaded on NPs & - & A. baumannii & $\begin{array}{l}533+170 \mu \mathrm{g} / \mathrm{mL} \\
(\mathrm{OMP}+\text { chitosan) } \\
\text { 1st and 3rd week: } \\
0.5 \mathrm{~mL} ; 5 \text { th week: } 1 \mathrm{~mL}\end{array}$ & $\begin{array}{l}\text { Modulate cytokine profile; trigger immune } \\
\text { response; act as nano-vaccine }\end{array}$ & [92] \\
\hline \multicolumn{7}{|c|}{ Inorganic NPs } \\
\hline \multirow{4}{*}{ AgNPs } & & 12.05 & $\begin{array}{l}\text { A. baumannii SRMC } 27 ; \\
\text { A. haemolyticus MMC } 8\end{array}$ & $2000 \mu \mathrm{g} / \mathrm{mL}$ & $80 \%-92 \%$ biofilm inhibition and disruption & [94] \\
\hline & & $21-29$ & $\begin{array}{l}\text { A. baumannii ATCC } \\
\text { BAA- } 1605\end{array}$ & $250-1000 \mathrm{mg} / \mathrm{mL}$ & $\begin{array}{l}\text { Biofilm disruption on polycarbonate } \\
\text { membrane; 4-log reduction in cell load at } \\
\text { highest concentration }\end{array}$ & [91] \\
\hline & Combined with imipenem & - & A. baumannii & $0.0003-0.8 \mu \mathrm{g} / \mathrm{mL}$ & $\begin{array}{l}\text { Synergistic action; reduced MBIC } \\
\text { and MBEC }\end{array}$ & [95] \\
\hline & & 60 & A. baumannii AIIMS 7 & $1024 \mu \mathrm{g} / 200 \mu \mathrm{L}$ well & $\begin{array}{l}96 \%-99 \% \text { biofilm inhibition; } 88 \% \\
\text { eradication; change in cell morphology }\end{array}$ & [15] \\
\hline AuNPs & Vancomycin bound & - & A. baumannii & - & $\begin{array}{l}\text { Hyperthermic bactericidal action via } \\
\text { NIR irradiation }\end{array}$ & [96] \\
\hline \multirow{2}{*}{$\begin{array}{l}\text { Silver-gold } \\
\text { bimetallic NPs }\end{array}$} & & 90 & A. baumannii AIIMS 7 & $1024 \mu \mathrm{g} / 200 \mu \mathrm{L}$ well & $\begin{array}{l}93 \%-98 \% \text { biofilm inhibition; } 61 \%-77 \% \\
\text { eradication; cell lysis }\end{array}$ & [15] \\
\hline & $\mathrm{Au}$ (core) and Ag (shell) & $13-19$ & A. baumannii & $100 \mu \mathrm{g} / \mathrm{mL}$ & $83 \%$ biofilm inhibition & [14] \\
\hline SeNPs & - & $100-250$ & $\begin{array}{l}\text { Acinetobacter sp. } \\
(4117,1677,2030,674, \\
2020,1370)\end{array}$ & $1.2-3.6 \mu \mathrm{g} / \mathrm{mL}$ & $\begin{array}{l}\text { Dose-dependent anti-biofilm activity; } \\
75 \% \text { reduction }\end{array}$ & [89] \\
\hline $\begin{array}{l}\text { Nitric oxide-releasing } \\
\text { NPs }\end{array}$ & $\begin{array}{l}\text { Composite matrix of TMO, PEG, } \\
\text { chitosan and glucose with } \\
\text { sodium nitrite }\end{array}$ & 10 & A. baumannii 0057 & $5 \mathrm{mg}$ & $\begin{array}{l}\text { Reduced wound healing time in vivo; } \\
\text { reduced inflammatory response; inhibited } \\
\text { collagen degradation; induced } \\
\text { cytokine expression }\end{array}$ & [93] \\
\hline
\end{tabular}


Table 1. Cont

\begin{tabular}{|c|c|c|c|c|c|c|}
\hline NPs & Composition and Surface Property & Size (nm) & Acinetobacter Strain & Applied Dosage of NPs & Remarks & Ref. \\
\hline \multicolumn{7}{|c|}{ Nanocomposites } \\
\hline $\begin{array}{l}\mathrm{Cu}^{1} \text {-based NPs in } \\
\text { natural cellulose }\end{array}$ & Bare metal or metal oxide coating & $<5$ & A. baumannii & $\begin{array}{l}\sim 30 \mu \mathrm{g} \mathrm{Cu} \text { in } \\
\text { liquid culture }\end{array}$ & Bactericidal action without cytotoxicity & [97] \\
\hline $\begin{array}{l}\mathrm{Ag}^{1} \text {-based NPs in } \\
\text { natural cellulose }\end{array}$ & Bare metal or metal oxide coating & - & A. baumannii & $\begin{array}{l}\sim 12 \mu \mathrm{g} \mathrm{Ag} \text { in } \\
\text { liquid culture }\end{array}$ & $\begin{array}{l}\text { Bactericidal activity; toxic to NIH 3T3 } \\
\text { cell line }\end{array}$ & [97] \\
\hline Ag-exchanged zeolite & Coated with D-tyrosine & $500-1500$ & A. baumannii ST145 & - & $\begin{array}{l}\text { Complete bactericidal activity towards } \\
\text { immobilized cells; } 6.9-\log \text { cell reduction }\end{array}$ & {$[98]$} \\
\hline \multicolumn{7}{|c|}{ Bacteriophages } \\
\hline AB7-IBB1 & Siphoviridae family & $\begin{array}{l}50 \text { (head); } \\
240 \times 10 \text { (tail) }\end{array}$ & A. baumannii AIIMS 7 & $\begin{array}{l}\text { MOI } 10^{5} \text { with } 10^{2} \mathrm{CFU} \\
1 / \text { well }\end{array}$ & $\begin{array}{l}\text { Lyse } 23 \text { of } 39 \text { clinical isolates of } A \text {. baumannii; } \\
\text { affected biofilm formation on biotic and } \\
\text { abiotic surface; } 75 \% \text { eradication of biofilm }\end{array}$ & [99] \\
\hline AB7-IBB2 & Podoviridae family & $\begin{array}{l}35 \text { (head); } \\
7 \text { (tail) }\end{array}$ & A. baumannii AIIMS 7 & $\begin{array}{l}\text { MOI } 10^{5} \text { and } 10^{3} \text { with } 10^{2} \\
\text { and } 10^{4} \mathrm{CFU} / \text { well, } \\
\text { respectively }\end{array}$ & $\begin{array}{l}\text { Lyse } 19 \text { of } 39 \text { clinical isolates of } A \text {. baumannii; } \\
\text { affected biofilm formation on biotic and } \\
\text { abiotic surface; } 80 \% \text { eradication of biofilm }\end{array}$ & {$[100]$} \\
\hline
\end{tabular}

${ }^{1} \mathrm{NPs}$, nanoparticles; CPC, cetylpyridinium chloride; OMP, outer membrane protein; AgNPs; silver nanoparticles; MBIC, minimum biofilm inhibitory concentration; MBEC, minimum biofilm eradication concentration; AuNPs, gold nanoparticles; NIR, near infra-red; SeNPs, selenium nanoparticles; TMO, tetramethyl-orthosilicate; PEG, polyethylene glycol; Cu, copper; Ag, silver; MOI, multiplicity of infection; $\mathrm{CFU}$, colony-forming unit; "-" not reported. 


\subsection{Organic Nanoparticles}

\subsubsection{Liposomes and Nanoemulsions}

Liposomes are self-assembled lipid bilayers containing phospholipids, sterols, glycolipids, membrane proteins and hydrophilic polymers [101]. They resemble biological cell membranes, and can therefore act as effective drug-delivery systems. Antimicrobials can be encapsulated within the lipid bilayer (if hydrophobic), entrapped in the inner core (hydrophilic) or sequestered between the inner and outer bilayer interface (hydrophilic) of the liposome [101]. Liposomal antibiotic delivery studies have been pursued mainly in biofilm-forming P. aeruginosa [19,85,102]. However, in an interesting study, lipidic nanocapsules loaded with a mixture of carvacol and eugenol (phenols), cinnamaldehyde (aldehyde) and/or beta-caryophyllene (alkene) showed excellent in vitro antibacterial activity against $A$. baumannii. Intraperitoneal administration of this formulation resulted in increased survival in sepsis murine model [86]. Alipour et al. reported a decrease in bacterial count of A. baumannii and $A$. lwoffii when exposed to liposomal formulation of polymixin B (in 2:1 molar ratio of 1,2-dipalmitoyl-sn-glycero-3-phosphocholine and cholesterol). Reduction in minimum inhibitory concentration (MIC) of polymixin B was also observed [103]. Such encapsulations have the advantage of sustained and controlled release of drugs, thereby achieving effective drug-delivery and biofilm treatment with reduced cytotoxicity [101,104]. Moreover, these structures can be modified for targeted site-specific delivery.

Antimicrobial nanoemulsions-emulsified mixtures of detergent, oil and water with a particle size between 100-800 $\mathrm{nm}$-possess a broad range of microbicidal activity against bacteria, fungi and enveloped viruses [105]. Figure 2 shows the disruption of $A$. baumannii biofilm on exposure to nanoemulsion of cetylpyridinium chloride, a quaternary ammonium salt. The nanoemulsion not only penetrates the thick biofilm matrix but also damages the bacterial cells [90]. These emulsified nanoparticles act by fusing with lipid bilayers and destabilizing the cell membrane [106]. In addition to liposomes and nanoemulsions, solid lipid nanoparticles, lipoproteins and micelles can also be used for drug delivery [107].

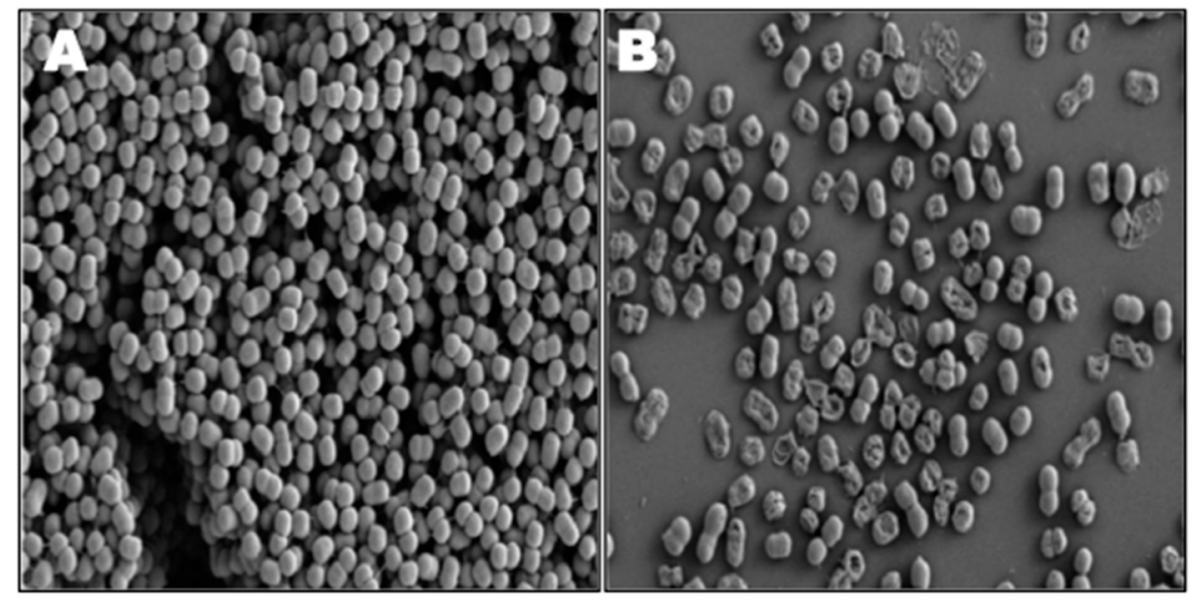

Figure 2. Scanning electron microscopy of MDR A. baumannii ATCC BAA-1605 biofilms. (A) Control; (B) Treatment with nanoemulsion of $1 \%$ cetylpyridinium chloride for $1 \mathrm{~h}$ (adapted from [90], with permission from (C) 2013 American Society for Microbiology).

\subsubsection{Polymeric Nanoparticles}

Polymers are multifunctional biomaterials that can be engineered for wide properties suitable for applications in medicine and pharmaceutical industry as drug carriers, surgical sutures, scaffolds and resorbable devices [108-110]. While some polymers possess antimicrobial activity due to specific functional groups, such as halogens, guanidine or quaternary nitrogen atom [111], few of the other 
polymers can also be loaded with antimicrobial agents. The functional groups on polymer nanoparticles can be modified or novel synthetic analogs can be designed to increase their specific activity and selectivity. Properties of biocompatible polymers can also be harnessed for in vivo applications. However, very few reports are available on inhibition and disruption of Acinetobacter biofilms through polymers [92,112]. Maleic anhydride-based amphiphillic polymers, containing amide side chains, disrupt surface established $A$. baumannii biofilms. These polymers also reduce the bacterial count in mice with chronic burn-wound infection [88]. Similar observation was seen with methacrylate polymers containing a 2-aminoimidazole subunit [112]. Chitosan nanoparticles act as adjuvant to carry outer membrane proteins of Acinetobacter and elicit excellent immune response in rats [92], indicating potential for developing a novel vaccine. Poly(lactic-co-glycolic acid) polymeric nanoparticles have been used for effective delivery of antibiotics to treat biofilm-forming microorganisms [113]. Nylon-3-polymers and antimicrobial polymeric hydrogels can also be employed for the control of MDR bacterial and fungal biofilms [114,115].

\subsection{Inorganic Nanoparticles}

\subsubsection{Silver Nanoparticles}

Silver and its compounds are well known for antimicrobial properties and have been widely used in medicine and therapeutics for treatment of wounds, burns and infections. Nano-sized silver particles, however, exhibit superior antimicrobial activity against both Gram-positive and Gram-negative pathogenic bacteria, mycobacteria, fungi and yeasts [87,116-118]. There are many reports confirming inhibition and disruption of biofilms on exposure to silver nanoparticles (AgNPs) [119,120]. These particles have been used as disinfectant filters and surface-coating materials for implants and medical devices to prevent bacterial growth and infection [119-122]. In an interesting study, AgNPs synthesized from environmental A. calcoaceticus showed excellent disruption capability on preformed biofilms of clinical A. baumannii and A. haemolyticus strains isolated from hospitals [94]. Similar results were observed with AgNPs synthesized through reduction by gallic acid [91] and root extract of Plumbago zeylanica, a medicinal plant [15]. Nanosilver, owing to its small size, can easily penetrate the thick EPS in biofilms [94].

Synergy between AgNPs and conventional drugs offers a promising approach to control biofilm-related infections. Exposure to a combination of AgNPs with various antibiotics increases the drug susceptibility of planktonic MDR A. baumannii [87]. Formulation of imipenem and AgNPs not only killed planktonic cells but also eradicated their biofilm [95]. Combined killing mechanism exerted by antibiotics and AgNPs increases the susceptibility of MDR strains towards antibiotics and makes it difficult for bacteria to thrive in biofilms. Such an approach will help in combating drug resistance among Acinetobacter species.

\subsubsection{Gold Nanoparticles}

Gold nanoparticles (AuNPs) provide stable, non-toxic and biocompatible alternative, which can be easily synthesized in various morphologies, such as nanospheres, nanorods, nanoshells and nanocrystals $[78,123]$. Since AuNPs exhibit biocompatibility, surface plasmon resonance and photothermal effect, they have found wide applications in sensors, diagnosis and cancer treatment. Although few reports describe the antibacterial activity of AuNPs [124,125], Salunke and coworkers reported poor efficacy of chemical and phytogenic AuNPs to inhibit and disrupt A. baumannii biofilm [15]. However, these particles are known to carry therapeutic payloads, such as antibiotics, bound to them by covalent bonding, electrostatic adsorption, encapsulation or non-covalent interactions [126,127]. These moieties are triggered through internal and external stimuli [126]. For example, vancomycin-bound AuNPs showed successful hyperthermic killing of Gram-positive and Gram-negative pathogens including PDR A. baumannii via near infra-red irradiation [96]. According to Cui et al., AuNPs alter membrane potential, decrease intracellular ATP levels, and inhibit activity of 
ATP synthase and tRNA-binding subunit of ribosome [125]. Surface modification of AuNPs has also been suggested to control their inhibitory effects [128].

\subsubsection{Selenium Nanoparticles}

Selenium nanoparticles (SeNPs) exhibit good absorption capacity, higher bioavailability and reduced cytotoxicity to have medicinal applicability [81]. However, only a single study demonstrated the anti-biofilm activity of actinobaterially synthesized SeNPs. Complete biofilm inhibition in six drug-resistant Acinetobacter strains was observed at $3.2 \mu \mathrm{g}$ concentration of SeNPs in $48 \mathrm{~h}$ [89]. Mechanism of antibacterial action is still unknown.

\subsubsection{Nitric-Oxide Releasing Nanoparticles}

Nitric oxide (NO) is a lipophilic, short-lived free radical with a very small size that allows it to easily diffuse across membranes and interact with both extra- and intra-cellular components [3]. $\mathrm{NO}$ and its derivatives cause nitrosative stress on biological membranes and DNA damage through $\mathrm{N}$-nitrosation and oxidative cleavage; they also interact with thiol-containing protein via S-nitrosation and provoke lipid peroxidation leading to membrane disruption [129]. Exposure to low doses of NO restores biofilm sensitivity towards a variety of antimicrobial agents, thereby increasing their efficacy in dispersing bacteria [3]. Topical application of NO-releasing nanoparticles $(\sim 10 \mathrm{~nm})$ reduces the bacterial load, inflammation and collagen degradation, as well as modulates cytokine response with a substantial decrease in healing time in A. baumannii wound infection [93]. Since their formulation can only be applied on the skin surface, the use is prevented in common Acinetobacter infections, bacteremia and pneumonia [71]; however, they make an attractive alternative for environmental biocontrol and treatment of wounds, burns and other skin-related infections.

\subsubsection{Multi-Metallic Nanoparticles}

Use of bi- and tri-metallic nanoparticles is a great approach whereby, instead of a single metal, properties of two or more metals can be exploited. Such nanoparticles exhibit enhanced medicinal and therapeutic efficacy and are required in low concentrations to achieve a similar bactericidal effect as that with mono-metallic ones. Phytogenic silver-gold bimetallic nanoparticles from root extract of $P$. zeylanica showed significant inhibition and disruption of preformed Acinetobacter biofilm [15]. In another report, gold-silver core-shell nanoparticles from medicinal plant Dioscorea bulbifera inhibit biofilm formation among both Gram-positive and Gram-negative bacteria, including A. baumannii [14]. The bactericidal effect from these nanoparticles is due to cell-wall damage causing efflux of cellular materials, which may be attributed to the presence of silver [14,15]. Once the pores are made in the cell wall, silver and gold interact with cellular components and DNA to cause more destruction to bacteria. Although no report describes the efficacy of tri-metallic nanoparticles in control of Acinetobacter biofilm, the study of Mahmoodi and Serpooshan confirmed that chemically prepared tri-metallic SPIONs, consisting of gold and silver shells onto iron core, have profound anti-biofilm potency against S. aureus and S. epidermidis [18].

\subsection{Nanoconjugates, Nanoalloys and Nanocomposites}

Thus far, nanoconjugates and nanoalloys have not been employed to inhibit Acinetobacter colonization. However, profound reduction in A. baumannii has been reported on treatment with nanocomposites, synthesized by copper-based nanostructured coating on natural cellulose substrate. Relatively low efficacy was observed with similar silver-coated nanocomposite [97]. Studies have confirmed antibacterial and anti-biofouling activity of micron-sized alloys and composites [98,130], which is dependent on the constituents, type of surface and coating materials. For example, surface modification of titanium implants through doping with silver and/or gallium enhances antibacterial effectiveness against MDR A. baumannii [130]. Figure 3 depicts $100 \%$ killing of $A$. baumannii on a composite containing silver-exchanged natural zeolite and poly(vinyl chloride), coated with D-tyrosine. 
Uncoated composite inhibits the biofilm formation on the surface with only $70 \%$ reduction in bacterial load [98]. D-tyrosine gets incorporated into the peptidoglycan layer of the bacterial cell wall and replaces D-alanine, thereby disrupting the cell connection with the biofilm matrix [58,131,132].
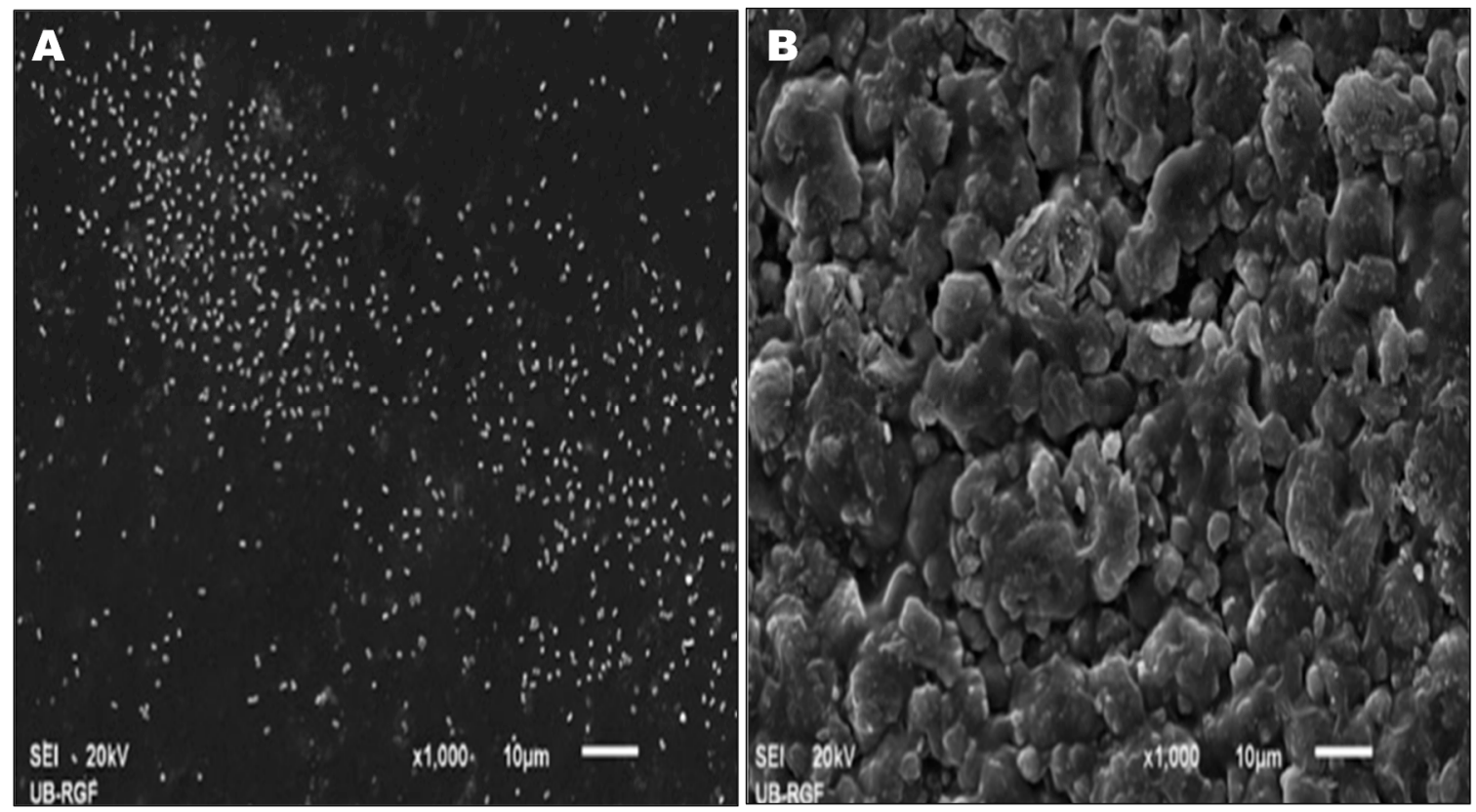

Figure 3. Effect of D-tyrosine coating on composite. (A) A. baumannii cells without biofilm formation on uncoated composite; (B) Absence of bacterial cells on composite coated with D-tyrosine. One side of the composite surface was (A) shiny while other side was (B) coarse (obtained from [98], with permission from (C) 2014 Taylor \& Francis Ltd).

\subsection{Bacteriophages as Living Nanobullets}

Lytic phage therapy employs viruses that infect and lyse the bacterial cells. Lytic phages specific to clinical and MDR Acinetobacter strains have been isolated from sewage, marine water, patient sputum, etc. [71]. Two phages, AB7-IBB1 and AB7-IBB2, specific to A. baumannii AIIMS 7 reported from our laboratory have been shown to act as anti-biofilm agents inhibiting biofilm formation and eradicating up to $75 \%$ preformed biofilm $[99,100]$. In another study, a cocktail of phages was observed to lyse 113 of 127 A. baumannii strains [133], indicating their utility in hospital and environmental biocontrol. However, host-range specificity and in vivo studies need further investigation.

\section{Resistance towards Nanoparticles}

Conventional drugs are losing their functional value due to the rapidly developing drug resistance in microorganisms. This insusceptibility prompted researchers to exploit nanoparticles as an alternative approach to deal with aggressive pathogens like Acinetobacter. Multiple mechanisms have been reported to explain the bactericidal action of nanoparticles: they can penetrate EPS, disrupt cellular morphology, inactivate vital enzymes and proteins, denature proteins, generate ROS, inhibit DNA replication and prevent ribosome interactions [80,134-136]. Such multi-mode bactericidal action of nanoparticles is beneficial since bacteria would have to develop a number of mutations simultaneously to survive [80]. However, this raises concerns on the specificity of nanoparticles to kill a particular pathogen. Unlike traditional antibiotics, inherited resistance towards organic and inorganic nanoparticles has not been observed in bacteria. However, a recent study suggested that bacteria could evolve to acquire resistance through genetic mutations on continuous treatment with AgNPs for 225 generations [137]. Hence, care should be taken to avoid unintentional and unnecessary exposure of microorganisms towards these nanoparticles. 


\section{Future Prospects}

Acinetobacter spp. are emerging as biofilm-producing, multi-drug resistant (MDR) nosocomial pathogens due to which antibiotics and natural phytogenic extracts are rendered ineffective in their control. Although nanomaterials have shown a great potential to curb Acinetobacter threats, in-depth studies are required to develop a potent and permanent solution. First and foremost, nanoparticles effective against planktonic Acinetobacter should be investigated further for their biofilm-disruption activity. Among organic nanoparticles, solid lipid nanoparticles, nanoemulsions, lipoproteins and micelles can also be used for targeted drug-delivery systems. In spite of a large number of polymers, very few polymeric nanoparticles have been investigated. Recently, carbon nanotubes, graphenes and fullerenes have gained medicinal significance and they may have potential to prevent Acinetobacter biofilms and infections. It is apparent from the earlier sections of this review that organic nanoparticles are effective mainly as drug-delivery vehicles owing to their biocompatible nature and ease of surface modification. However, only a single study demonstrates the increased survival rate in a sepsis murine model [86]. Although Acinetobacter species are well known to cause various biofilm-related internal infections, there are no reports on in vivo testing of these nanoparticles on established biofilms of Acinetobacter.

There are a number of reports on bactericidal and biofilm-disruption activity of metal and metal oxide nanoparticles of copper, titanium, titanium oxide, zinc, zinc oxide and iron. In addition to these, therapies based on gallium, magnesium, calcium and aluminum-derived nanoparticles can also be used. Inorganic nanoparticles, though they exhibit excellent bactericidal properties, always encounter biocompatibility, cytotoxicity and genotoxicity concerns. For these reasons, many researchers do not recommend their in vivo applications. On the contrary, reports are available supporting the non-toxic nature of metal nanoparticles $[79,97]$. Therefore, there is a need for further investigation to have a clear understanding of the toxicity aspect of these nanoparticles. The possibility of a balanced dosage of nanoparticles to achieve effective treatment without side effects cannot be ruled out.

In addition, a combination of metals and/or polymers in the form of nanoconjugates, nanoalloys and nanocomposites can be developed to enhance their biocompatibility and biofilm-disruption activity. Synergistic action of nanoparticles in combination with various antibiotics resulted in excellent inhibition of bacteria in planktonic stage. These combinations not only render ineffective antibiotics to kill bacteria efficiently, but also reduce their minimum inhibitory concentration (MIC). This synergistic approach will certainly reduce the therapeutic dose to cure the bacterial infections, thereby reducing the toxicity risks. Furthermore, formulations of nanoparticles should be developed for topical application. These will prove to be very helpful in treatment of burns and injuries, healing wounds and prevention of Acinetobacter infections. Application of nanomaterials should also be investigated as coating agents on surfaces of medical devices, implants, contact lenses and industrial machineries. Source, surface, composition and morphology-dependent action of nanoparticles should be evaluated. Although phage therapy is promising for hospital and environmental biocontrol, in vivo applications require further investigations. Host specificity of phages can be overcome by exposure to a phage cocktail.

Along with the factors influencing biofilm formation, physiological adaptation to stress, slower metabolism and increased expression of biofilm-specific traits-such as accumulation of $\beta$-lactamases, periplasmic antibiotic-binding polysaccharides, type IV pili or upregulation of enzymes to protect against endogenous oxidative stress, outer membrane proteins and porin channels-have been suggested to play a significant role in biofilms. Nanoparticles have been shown to penetrate the extracellular polymeric substances (EPS) of biofilms causing its disruption. However, detailed studies are required on molecular and genetic expression in biofilm, in response to treatment with nanoparticles, to elucidate the bactericidal and biofilm-disrupting mechanisms of nanoparticles. This will certainly aid in combating MDR biofilms and development of novel nano-formulations.

Acknowledgments: Richa Singh and Sweety Wadhwani thank the University Grants Commission, New Delhi, India for senior research fellowship. 
Author Contributions: B.A.C. and R.S. conceived the subject of review. R.S. and S.W. performed the literature survey. R.S. wrote the manuscript. S.N. and U.S. compiled the information about resistance in Acinetobacter. B.A.C. corrected the drafts and approved the final manuscript.

Conflicts of Interest: The authors declare no conflict of interest.

\section{References}

1. Hoiby, N.; Bjarnsholt, T.; Givskov, M.; Molin, S.; Ciofu, O. Antibiotic resistance of bacterial biofilms. Int. J. Antimicrob. Agents 2010, 35, 322-332. [CrossRef] [PubMed]

2. Branda, S.S.; Vik, A.; Friedman, L.; Kolter, R. Biofilms: The matrix revisited. Trends Microbiol. 2005, 13, $20-26$. [CrossRef] [PubMed]

3. Barraud, N.; Kelso, M.J.; Rice, S.A.; Kjelleberg, S. Nitric oxide: A key mediator of biofilm dispersal with applications in infectious diseases. Curr. Pharm. Des. 2015, 21, 31-42. [CrossRef] [PubMed]

4. Jefferson, K.K. What drives bacteria to produce a biofilm? FEMS Microbiol. Lett. 2004, 236, 163-173. [CrossRef] [PubMed]

5. Hall-Stoodley, L.; Costerton, J.W.; Stoodley, P. Bacterial biofilms: From the natural environment to infectious diseases. Nat. Rev. Microbiol. 2004, 2, 95-108. [CrossRef] [PubMed]

6. Donlan, R.M. Biofilm formation: A clinically relevant microbiological process. Clin. Infect. Dis. 2001, 33, 1387-1392. [CrossRef] [PubMed]

7. Costerton, J.W.; Lewandowski, Z.; Caldwell, D.E.; Korber, D.R.; Lappin-Scott, H.M. Microbial biofilms. Annu. Rev. Microbiol. 1995, 49, 711-745. [CrossRef] [PubMed]

8. National Institute of Health Guide: Research on Microbial Biofilms. Available online: http://grants.nih.gov/ grants/guide/pa-files/PA-03-047.html (accessed on 9 May 2016).

9. Potera, C. Forging a link between biofilms and disease. Science 1999, 283, 1837-1839. [CrossRef] [PubMed]

10. Chang, W.S.; van de Mortel, M.; Nielsen, L.; de Guzman, G.N.; Li, X.; Halverson, L.J. Alginate production by Pseudomonas putida creates a hydrated microenvironment and contributes to biofilm architecture and stress tolerance under water-limiting conditions. J. Bacteriol. 2007, 189, 8290-8299. [CrossRef] [PubMed]

11. Elasri, M.O.; Miller, R.V. Study of the response of a biofilm bacterial community to UV radiation. Appl. Environ. Microbiol. 1999, 65, 2025-2031. [PubMed]

12. Goodman, S.D.; Obergfell, K.P.; Jurcisek, J.A.; Novotny, L.A.; Downey, J.S.; Ayala, E.; Tjokro, A.N.; Li, B.; Justice, S.S.; Bakaletz, L.O. Biofilms can be dispersed by focusing the immune system on a common family of bacterial nucleoid-associated proteins. Mucosal Immunol. 2011, 4, 625-637. [CrossRef] [PubMed]

13. Prabhakara, R.; Harro, J.M.; Leid, J.G.; Harris, M.; Shirtliff, M.E. Murine immune response to a chronic Staphylococcus aureus biofilm infection. Infect. Immun. 2011, 79, 1789-1796. [CrossRef] [PubMed]

14. Ghosh, S.; Jagtap, S.; More, P.; Shete, U.J.; Maheshwari, N.O.; Rao, S.J.; Kitture, R.; Kale, S.; Bellare, J.; Patil, S.; et al. Dioscorea bulbifera mediated synthesis of novel $\mathrm{Au}_{\mathrm{core}}-\mathrm{Ag}_{\text {shell }}$ nanoparticles with potent antibiofilm and antileishmanial activity. J. Nanomater. 2015, 2015, 562938. [CrossRef]

15. Salunke, G.R.; Ghosh, S.; Santoshkumar, R.J.; Khade, S.; Vashisth, P.; Kale, T.; Chopade, S.; Pruthi, V.; Kundu, G.; Bellare, J.R.; et al. Rapid efficient synthesis and characterization of silver, gold and bimetallic nanoparticles from the medicinal plant Plumbago zeylanica and their application in biofilm control. Int. J. Nanomedicine 2014, 9, 2635-2653. [PubMed]

16. Sahu, P.K.; Iyer, P.S.; Oak, A.M.; Pardesi, K.R.; Chopade, B.A. Characterization of eDNA from the clinical strain Acinetobacter baumannii AIIMS 7 and its role in biofilm formation. Sci. World J. 2012, 2012, 973436. [CrossRef] [PubMed]

17. Sahu, P.K.; Iyer, P.S.; Gaikwad, M.B.; Talreja, S.C.; Pardesi, K.R.; Chopade, B.A. An MFS transporter-like ORF from MDR Acinetobacter baumannii AIIMS 7 is associated with adherence and biofilm formation on biotic/abiotic surface. Int. J. Microbiol. 2012, 2012, 490647. [CrossRef] [PubMed]

18. Mahmoodi, M.; Serpooshan, V. Silver-coated engineered magnetic nanoparticles are promising for the success in the fight against antibacterial resistance threat. ACS Nano 2012, 6, 2656-2664. [CrossRef] [PubMed]

19. Halwani, M.; Hebert, S.; Suntres, Z.E.; Lafrenie, R.M.; Azghani, A.O.; Omri, A. Bismuth-thiolincorporation enhances biological activities of liposomal tobramycin against bacterial biofilm and quorum sensing molecules production by Pseudomonas aeruginosa. Int. J. Pharm. 2009, 373, 141-146. [CrossRef] [PubMed] 
20. Dow, J.M.; Crossman, L.; Findlay, K.; He, Y.Q.; Feng, J.X.; Tang, J.L. Biofilm dispersal in Xanthomonas campestris is controlled by cell-cell signaling and is required for full virulence to plants. Proc. Natl. Acad. Sci. USA 2003, 100, 10995-11000. [CrossRef] [PubMed]

21. Visca, P.; Seifert, H.; Towner, K.J. Acinetobacter infection- an emerging threat to human health. IUBMB Life 2011, 63, 1048-1054. [CrossRef] [PubMed]

22. Rokhbakhsh-Zamin, F.; Sachdev, D.; Kazemi-Pour, N.; Engineer, A.; Pardesi, K.R.; Zinjarde, S.; Dhakephalkar, P.K.; Chopade, B.A. Characterization of plant-growth-promoting traits of Acinetobacter species isolated from rhizosphere of Pennisetum glaucum. J. Microbiol. Biotechnol. 2011, 21, 556-566. [PubMed]

23. Sachdev, D.; Nema, P.; Dhakephalkar, P.; Zinjarde, S.; Chopade, B. Assessment of 16S rRNA gene-based phylogenetic diversity and promising plant growth-promoting traits of Acinetobacter community from the rhizosphere of wheat. Microbiol. Res. 2010, 165, 627-638. [CrossRef] [PubMed]

24. Huddedar, S.B.; Shete, A.M.; Tilekar, J.N.; Gore, S.D.; Dhavale, D.D.; Chopade, B.A. Isolation, characterization and plasmid pUPI126-mediated indole-3-acetic acid production in Acinetobacter strains from rhizosphere of wheat. Appl. Biochem. Biotechnol. 2002, 103, 21-39. [CrossRef]

25. Deshpande, L.M.; Kapadnis, B.P.; Chopade, B.A. Metal resistance in Acinetobacter and its relation to beta-lactamse production. Biometals 1993, 6, 55-59. [CrossRef] [PubMed]

26. Saha, S.C.; Chopade, B.A. Effect of food preservatives on Acinetobacter genospecies isolated from meat. J. Food Sci. Technol. 2002, 39, 26-32.

27. Saha, S.C.; Chopade, B.A. Studies on occurrence and distribution of Acinetobacter spp. and other gram-negative bacterial from meat. J. Food Sci. Technol. 2001, 38, 17-22.

28. Yavankar, S.P.; Pardesi, K.R.; Chopade, B.A. Species distribution and physiological characterization of Acinetobacter genospecies from healthy human skin of tribal population in India. Indian J. Med. Microbiol. 2007, 25, 336-345. [PubMed]

29. Jagtap, S.; Gore, S.; Yavankar, S.; Pardesi, K.; Chopade, B. Optimization of medium for lipase production by Acinetobacter haemolyticus from healthy human skin. Indian J. Exp. Biol. 2010, 48, 936-941. [PubMed]

30. Pendleton, J.N.; Gorman, S.P.; Gilmore, B.F. Clinical relevance of the ESKAPE pathogens. Expert Rev. Anti Infect. Ther. 2013, 11, 297-308. [CrossRef] [PubMed]

31. Shakibaie, M.R.; Dhakephalkar, P.K.; Kapadnis, B.P.; Chopade, B.A. Silver resistance in Acinetobacter baumannii BL54 occurs through binding to a Ag-binding protein. Iran. J. Biotechnol. 2003, 1, 41-46.

32. Pour, N.K.; Dusane, D.H.; Dhakephalkar, P.K.; Zamin, F.R.; Zinjarde, S.S.; Chopade, B.A. Biofilm formation by Acinetobacter baumannii strains isolated from urinary tract infection and urinary catheters. FEMS Immunol. Med. Microbiol. 2011, 62, 328-338. [CrossRef] [PubMed]

33. Patwardhan, R.B.; Dhakephalkar, P.K.; Niphadkar, K.B.; Chopade, B.A. A study on nosocomial pathogens in ICU with special reference to multiresistant Acinetobacter baumannii harbouring multiple plasmids. Indian J. Med. Res. 2008, 128, 178-187. [PubMed]

34. Bergogne-Berezin, E.; Towner, K.J. Acinetobacter spp. as nosocomial pathogens: Microbiological, clinical and epidemiological features. Clin. Microbiol. Rev. 1996, 9, 148-165. [PubMed]

35. Dijkshoorn, L.; Nemec, A.; Seifert, H. An increasing threat in hospitals: Multidrug-resistant Acinetobacter baumannii. Nat. Rev. Microbiol. 2007, 5, 939-951. [CrossRef] [PubMed]

36. Patil, J.R.; Jog, N.R.; Chopade, B.A. Isolation and characterization of Acinetobacter spp. from upper respiratory tract of healthy humans and demonstration of lectin activity. Indian J. Med. Microbiol. 2001, 19, 30-35.

37. Patil, J.R.; Chopade, B.A. Distribution and in vitro antimicrobial susceptibility of Acinetobacter species on the skin of healthy humans. Natl. Med. J. India 2001, 14, 204-208. [PubMed]

38. Manchanda, V.; Sinha, S.; Singh, N.P. Multidrug Resistant Acinetobacter. J. Glob. Infect. Dis. 2010, 2, $291-304$. [CrossRef] [PubMed]

39. Litzler, P.Y.; Benard, L.; Barbier-Frebourg, N.; Vilain, S.; Jouenne, T.; Beucher, E.; Bunel, C.; Lemeland, J.F.; Bessou, J.P. Biofilm formation on pyrolytic carbon heart valves: Influence of surface free energy, roughness, and bacterial species. J. Thorac. Cardiovasc. Surg. 2007, 134, 1025-1032. [CrossRef] [PubMed]

40. Dallo, S.F.; Weitao, T. Insights into Acinetobacter war-wound infections, biofilms and control. Adv. Skin Wound Care 2010, 23, 169-174. [CrossRef] [PubMed]

41. Tien, H.C.; Battad, A.; Bryce, E.A. Multi-drug resistant Acinetobacter infections in critically injured Canadian forces soldiers. BMC Infect. Dis. 2007, 7, 95. [CrossRef] [PubMed] 
42. Aronson, N.E.; Sanders, J.W.; Moran, K.A. In harm's way: Infections in deployed American military forces. Clin. Infect. Dis. 2006, 43, 1045-1051. [CrossRef] [PubMed]

43. Charnot-Katsikas, A.; Dorafshar, A.H.; Aycock, J.K.; David, M.Z.; Weber, S.G.; Frank, K.M. Two cases of necrotizing fasciitis due to Acinetobacter baumannii. J. Clin. Microbiol. 2009, 47, 258-263. [CrossRef] [PubMed]

44. Falagas, M.E.; Karveli, E.A.; Kelesidis, I.; Kelesidis, T. Community acquired Acinetobacter infections. Eur. J. Clin. Microbiol. Infect. Dis. 2007, 26, 857-868. [CrossRef] [PubMed]

45. Lee, H.W.; Koh, Y.M.; Kim, J.; Lee, J.C.; Lee, Y.C.; Seol, S.Y.; Cho, D.T.; Kim, J. Capacity of multidrug-resistant clinical isolates of Acinetobacter baumannii to form biofilm and adhere to epithelial cell surfaces. Clin. Microbiol. Infect. 2008, 14, 49-54. [CrossRef] [PubMed]

46. Gaidhani, S.V.; Raskar, A.V.; Poddar, S.; Gosavi, S.; Sahu, P.K.; Pardesi, K.R.; Bhide, S.V.; Chopade, B.A. Time dependent enhanced resistance against antibiotics and metal salts by planktonic and biofilm form of Acinetobacter haemolyticus MMC 8 clinical isolate. Indian J. Med. Res. 2014, 140, 665-671. [PubMed]

47. Wong, H.S.; Townsend, K.M.; Fenwick, S.G.; Trengove, R.D.; O’Handley, R.M. Comparative susceptibility of planktonic and 3-day-old Salmonella typhimurium biofilms to disinfectants. J. Appl. Microbiol. 2010, 108, 2222-2228. [CrossRef] [PubMed]

48. Langsrud, S.; Sidhu, M.S.; Heir, E.; Holck, A.L. Bacterial disinfectant resistance-A challenge for the food industry. Int. Biodeterior. Biodegr. 2003, 51, 283-290. [CrossRef]

49. Russell, A.D. Similarities and differences in the responses of microorganisms to biocides. J. Antimicrob. Chemother. 2003, 52, 750-763. [CrossRef] [PubMed]

50. Ghannoum, M.; O’Toole, G.A. Microbial Biofilms; ASM Press: Washington, DC, USA, 2004.

51. Donlan, R.M. Biofilms: Microbial life on surfaces. Emerg. Infect. Dis. 2002, 8, 881-890. [CrossRef] [PubMed]

52. Kalia, V.C. Quorum sensing inhibitors: An overview. Biotechnol. Adv. 2013, 31, 224-245. [CrossRef] [PubMed]

53. Tomaras, A.P.; Dorsey, C.W.; Edelmann, R.E.; Actis, L.A. Attachment to and biofilm formation on abiotic surfaces by Acinetobacter baumannii: Involvement of a novel chaperone-usher pili assembly system. Microbiology 2003, 149, 3473-3484. [CrossRef] [PubMed]

54. Loehfelm, T.W.; Luke, N.R.; Campagnari, A.A. Identification and characterization of an Acinetobacter baumannii biofilm-Associated protein. J. Bacteriol. 2008, 190, 1036-1044. [CrossRef] [PubMed]

55. Sahu, P.K.; Iyer, P.S.; Barage, S.H.; Sonawane, K.D.; Chopade, B.A. Characterization of the algC gene expression pattern in the multidrug resistant Acinetobacter baumannii AIIMS 7 and correlation with biofilm development on abiotic surface. Sci. World J. 2014, 2014, 593546. [CrossRef] [PubMed]

56. Schleheck, D.; Barraud, N.; Klebensberger, J.; Webb, J.S.; McDougald, D.; Rice, S.A.; Kjelleberg, S. Pseudomonas aeruginosa PAO1 preferentially grows as aggregates in liquid batch cultures and disperses upon starvation. PLoS ONE 2009, 4, e5513. [CrossRef] [PubMed]

57. Musk, D.J.; Banko, D.A.; Hergenrother, P.J. Iron salts perturb biofilm formation and disrupt existing biofilms of Pseudomonas aeruginosa. Chem. Biol. 2005, 12, 789-796. [CrossRef] [PubMed]

58. Kolodkin-Gal, I.; Romero, D.; Cao, S.; Clardy, J.; Kolter, R.; Losick, R. D-amino acids trigger biofilm disassembly. Science 2010, 328, 627-629. [CrossRef] [PubMed]

59. Davies, D.G.; Marques, C.N. A fatty acid messenger is responsible for inducing dispersion in microbial biofilms. J. Bacteriol. 2009, 191, 1393-1403. [CrossRef] [PubMed]

60. Römling, U.; Galperin, M.Y.; Gomelsky, M. Cyclic di-GMP: The first 25 years of a universal bacterial second messenger. Microbiol. Mol. Biol. Rev. 2013, 77, 1-52. [CrossRef] [PubMed]

61. Ragas, X.; Dai, T.; Tegos, G.P.; Agut, M.; Nonell, S.; Hamblin, M.R. Photodynamic inactivation of Acinetobacter baumannii using phenothiazinium dyes: In vitro and in vivo studies. Lasers Surg. Med. 2010, 42, 384-390. [CrossRef] [PubMed]

62. López-Rojas, R.; Docobo-Pérez, F.; Pachón-Ibáñez, M.E.; de la Torre, B.G.; Fernández-Reyes, M.; March, C.; Bengoechea, J.A.; Andreu, D.; Rivas, L.; Pachón, J. Efficacy of cecropin A-melittin peptides on a sepsis model of infection by pan-resistant Acinetobacter baumannii. Eur. J. Clin. Microbiol. Infect. Dis. 2011, 30, 1391-1398. [CrossRef] [PubMed]

63. Fattahian, Y.; Rasooli, I.; MousaviGargari, S.L.; Rahbar, M.R.; Darvish Alipour Astaneh, S.; Amani, J. Protection against Acinetobacter baumannii infection via its functional deprivation of biofilm associated protein (Bap). Microb. Pathog. 2011, 51, 402-406. [CrossRef] [PubMed] 
64. Luo, G.; Lin, L.; Ibrahim, A.S.; Baquir, B.; Pantapalangkoor, P.; Bonomo, R.A.; Doi, Y.; Adams, M.D.; Russo, T.A.; Spellberg, B. Active and passive immunization protects against lethal, extreme drug resistant-Acinetobacter baumannii infection. PLoS ONE 2012, 7, e29446. [CrossRef] [PubMed]

65. Bentancor, L.V.; O’Malley, J.M.; Bozkurt-Guzel, C.; Pier, G.B.; Maira-Litan, T. Poly-N-acetyl-beta-(1-6)glucosamine is a target for protective immunity against Acinetobacter baumannii infections. Infect. Immun. 2012, 80, 651-656. [CrossRef] [PubMed]

66. Bentancor, L.V.; Routray, A.; Bozkurt-Guzel, C.; Camacho-Peiro, A.; Pier, G.B.; Maira-Litan, T. Evaluation of the trimeric auto-transporter Ata as a vaccine candidate against Acinetobacter baumannii infections. Infect. Immun. 2012, 80, 3381-3388. [CrossRef] [PubMed]

67. Conlon, J.M.; Ahmed, E.; Codamine, E. Antimicrobial properties of brevinin-2-related peptide and its analogs: Efficacy against multidrug-resistant Acinetobacter baumannii. Chem. Biol. Drug Des. 2009, 74, 488-493. [CrossRef] [PubMed]

68. Conlon, J.M.; Mechkarska, M.; Arafat, K.; Attoub, S.; Sonnevend, A. Analogues of the frog skin peptide alyteserin-2a with enhanced antimicrobial activities against Gram-negative bacteria. J. Pept. Sci. 2012, 18, 270-275. [CrossRef] [PubMed]

69. Conlon, J.M.; Sonnevend, A.; Pal, T.; Vila-Farres, X. Efficacy of six frog skin-derived antimicrobial peptides against colistin-resistant strains of the Acinetobacter baumannii group. Int. J. Antimicrob. Agents 2012, 39, 317-320. [CrossRef] [PubMed]

70. Hamblin, M.R.; Hasan, T. Photodynamic therapy: A new antimicrobial approach to infectious disease? Photochem. Photobiol. Sci. 2004, 3, 436-450. [CrossRef] [PubMed]

71. García-Quintanilla, M.; Pulido, M.R.; López-Rojas, R.; Pachón, J.; McConnell, M.J. Emerging therapies for multidrug resistant Acinetobacter baumannii. Trends Microbiol. 2013, 21, 157-163. [CrossRef] [PubMed]

72. Neethirajan, S.; Clond, M.A.; Vogt, A. Medical biofilms- nanotechnology approaches. J. Biomed. Nanotech 2014, 10, 1-22. [CrossRef]

73. Kurkov, S.V.; Loftsson, T. Cyclodextrins. Int. J. Pharm. 2013, 453, 167-180. [CrossRef] [PubMed]

74. Patel, M.R.; Patel, R.B.; Parikh, J.R.; Solanki, A.B.; Patel, B.G. Investigating effect of microemulsion components: In vitro permeation of ketoconazole. Pharm. Dev. Technol. 2011, 16, 250-258. [CrossRef] [PubMed]

75. Feng, K.; Sun, H.; Bradley, M.A. Novel antibacterial nanofibrous PLLA scaffolds. J. Control. Release 2010, 146, 363-369. [CrossRef] [PubMed]

76. Johansson, E.M.V.; Crusz, S.A.; Kolomiets, E.; Buts, L.; Kadam, R.U.; Cacciarini, M.; Bartels, K.M.; Diggle, S.P.; Camara, M.; Williams, P.; et al. Inhibition and dispersion of Pseudomonas aeruginosa biofilms by glycopeptides dendrimers targeting the fucose-specific lectin LecB. Chem. Biol. 2008, 15, 1249-1257. [CrossRef] [PubMed]

77. Ghosh, S.; More, P.; Nitnavre, R.; Jagtap, S.; Chippalkatti, R.; Derle, A.; Kitture, R.; Asok, A.; Kale, S.; Singh, S.; et al. Antidiabetic and antioxidant properties of copper nanoparticles synthesized by medicinal plant Dioscorea bulbifera. J. Nanomed. Nanotechnol. 2015, S6, 007.

78. Shedbalkar, U.; Singh, R.; Wadhwani, S.; Gaidhani, S.; Chopade, B.A. Microbial synthesis of gold nanoparticles: Current status and future prospects. Adv. Colloid Interface Sci. 2014, 209, 40-48. [CrossRef] [PubMed]

79. Singh, R.; Nawale, L.; Arkile, M.; Wadhwani, S.; Shedbalkar, U.; Chopade, S.; Sarkar, D.; Chopade, B.A. Phytogenic silver, gold and bimetallic nanoparticles as novel antitubercular agents. Int. J. Nanomed. 2016, 11, 1889-1897.

80. Singh, R.; Shedbalkar, U.U.; Wadhwani, S.A.; Chopade, B.A. Bacteriagenic silver nanoparticles: Synthesis, mechanism, and applications. Appl. Microbiol. Biotechnol. 2015, 99, 4579-4593. [CrossRef] [PubMed]

81. Wadhwani, S.A.; Shedbalkar, U.U.; Singh, R.; Chopade, B.A. Biogenic selenium nanoparticles: Current status and future prospects. Appl. Microbiol. Biotechnol. 2016, 100, 2555-2566. [CrossRef] [PubMed]

82. Asok, A.; Ghosh, S.; More, P.A.; Chopade, B.A.; Gandhi, M.N.; Kulkarni, A.R. Surface defect rich $\mathrm{ZnO}$ quantum dots as antioxidants inhibiting $\alpha$-amylase and $\alpha$-glucosidase: A potential anti-diabetic nanomedicine. J. Mater. Chem. B 2015, 3, 4597-4606. [CrossRef]

83. Kitture, R.; Chordiya, K.; Gaware, S.; Ghosh, S.; More, P.A.; Kulkarni, P.; Chopade, B.A.; Kale, S.N. $\mathrm{ZnO}$ nanoparticles-red sandalwood conjugate: A promising anti-diabetic agent. J. Nanosci. Nanotechnol. 2015, 15, 4046-4051. [CrossRef] [PubMed] 
84. Mallick, A.; More, P.; Ghosh, S.; Chippalkatti, R.; Chopade, B.A.; Lahiri, M.; Basu, S. Dual drug conjugated nanoparticle for simultaneous targeting of mitochondria and nucleus in cancer cells. ACS Appl. Mater. Interfaces 2015, 7, 7584-7598. [CrossRef] [PubMed]

85. Alipour, M.; Dorval, C.; Suntres, Z.E.; Omri, A. Bismuth-ethanedithiol incorporated in a liposome loaded tobramycin formulation modulates the alginate levels in mucoid Pseudomonas aeruginosa. J. Pharm. Pharmacol. 2011, 63, 999-1007. [CrossRef] [PubMed]

86. Montagu, A.; Saulnier, P.; Cassissa, V.; Rossines, E.; Eveillard, M.; Joly-Guillou, M.-L. Aromatic and terpenic compounds loaded in lipidic nanocapsules: Activity against multi-drug resistant Acinetobacter baumannii assessed in vitro and in a murine model of sepsis. J. Nanomed. Nanotechnol. 2014, 5, 3.

87. Singh, R.; Wagh, P.; Wadhwani, S.; Gaidhani, S.; Kumbhar, A.; Bellare, J.; Chopade, B.A. Synthesis, optimization, and characterization of silver nanoparticles from Acinetobacter calcoaceticus and their enhanced antibacterial activity when combined with antibiotics. Int. J. Nanomed. 2013, 8, 4277-4290.

88. Uppu, D.S.S.M.; Samaddar, S.; Ghosh, C.; Paramanandham, K.; Shome, B.R.; Haldar, J. Amide side chain amphiphilic polymers disrupt surface established bacterial biofilms and protect mice from chronic Acinetobacter baumannii infection. Biomaterials 2016, 74, 131-143. [CrossRef] [PubMed]

89. Ramya, S.; Shanmugasundaram, T.; Balagurunathan, R. Biomedical potential of actinobacterially synthesized selenium nanoparticles with special reference to anti-biofilm, anti-oxidant, wound healing, cytotoxic and anti-viral activities. J. Trace Elem. Med. Biol. 2015, 32, 30-39. [CrossRef] [PubMed]

90. Hwang, Y.Y.; Ramalingam, K.; Bienek, D.R.; Lee, V.; You, T.; Alvarez, R. Antimicrobial activity of nano emulsion in combination with cetylpyridinium chloride in multidrug-resistant Acinetobacter baumannii. Antimicrob. Agents Chemother. 2013, 57, 3568-3575. [CrossRef] [PubMed]

91. Martinez-Gutierrez, F.; Boegli, L.; Agostinho, A.; Morales Sánchez, E.; Bach, H.; Ruiz, F.; James, G. Anti-biofilm activity of silver nanoparticles against different microorganisms. Biofouling 2013, 29, 651-660. [CrossRef] [PubMed]

92. Alzubaidi, A.N.A.; Alkozai, Z.M.F. Immunogenic properties of outer membrane protein of Acinetobacter baumannii that loaded on chitosan nanoparticles. Am. J. Biomed. 2015, 3, 59-74.

93. Mihu, M.R.; Sandkovsky, U.; Han, G.; Friedman, J.M.; Nosanchuk, J.D.; Martinez, L.R. Nitric oxide releasing nanoparticles are therapeutic for Acinetobacter baumannii wound infections. Virulence 2010, 1, 62-67. [CrossRef] [PubMed]

94. Gaidhani, S.; Singh, R.; Singh, D.; Patel, U.; Shevade, K.; Yeshvekar, R.; Chopade, B.A. Biofilm disruption activity of silver nanoparticles synthesized by Acinetobacter calcoaceticus PUCM 1005. Mater. Lett. 2013, 108, 324-327. [CrossRef]

95. Hendiani, S.; AhyaAbdi, A.; Mohammadi, P.; Kharrazi, S. Synthesis of silver nanoparticles and its synergistic effects in combination with imipenem and two biocides against biofilm producing Acinetobacter baumannii. Nanomed. J. 2015, 2, 291-298.

96. Huang, W.C.; Tsai, P.-J.; Chen, Y.C. Functional gold nanoparticles as photothermal agents for selective-killing of pathogenic bacteria. Nanomedicine 2007, 2, 777-787. [CrossRef] [PubMed]

97. Cady, N.C.; Behnke, J.L.; Strickland, A.D. Copper-based nanostructured coatings on natural cellulose: Nanocomposites exhibiting rapid and efficient inhibition of a multi-drug resistant wound pathogen, A. baumannii, and mammalian cell biocompatibility in vitro. Adv. Eng. Mater. 2011, 21, 2506-2514. [CrossRef]

98. Milenkovic, J.; Hrenovic, J.; Goic-Barisic, I.; Tomic, M.; Djonlagic, J.; Rajic, N. Synergistic anti-biofouling effect of Ag-exchanged zeolite and D-Tyrosine on PVC composite against the clinical isolate of Acinetobacter baumannii. Biofouling 2014, 30, 965-973. [CrossRef] [PubMed]

99. Yele, A.B.; Thawal, N.D.; Sahu, P.K.; Chopade, B.A. Novel lytic bacteriophage AB7-IBB1 of Acinetobacter baumannii: Isolation, characterization and its effect on biofilm. Arch. Virol. 2012, 157, 1441-1450. [CrossRef] [PubMed]

100. Thawal, N.D.; Yele, A.B.; Sahu, P.K.; Chopade, B.A. Effect of a novel podophage AB7-IBB2 on Acinetobacter baumannii biofilm. Curr. Microbiol. 2012, 65, 66-72. [CrossRef] [PubMed]

101. Sharma, A.; Sharma, U.S. Liposomes in drug delivery: Progress and limitations. Int. J. Pharm. 1997, 154, 123-140. [CrossRef]

102. Rukholm, G.; Mugabe, C.; Azghani, A.O.; Omri, A. Antibacterial activity of liposomal gentamicin against Pseudomonas aeruginosa: A time-kill study. Int. J. Antimicrob. Agents 2006, 27, 247-252. [CrossRef] [PubMed] 
103. Alipour, M.; Halwani, M.; Omri, A.; Suntres, Z.E. Antimicrobial effectiveness of liposomal polymyxin B against resistant Gram-negative bacterial strains. Int. J. Pharm. 2008, 355, 293-298. [CrossRef] [PubMed]

104. Lian, T.; Ho, R.J.Y. Trends and developments in liposome drug delivery systems. J. Pharm. Sci. 2001, 90, 667-680. [CrossRef] [PubMed]

105. Ramalingam, K.; Amaechi, B.T.; Ralph, R.H.; Lee, V.A. Antimicrobial activity of nanoemulsion on cariogenic planktonic and biofilm organisms. Arch. Oral Biol. 2012, 57, 15-22. [CrossRef] [PubMed]

106. Hemmila, M.R.; Mattar, A.; Taddonio, M.A.; Arbabi, S.; Hamouda, T.; Ward, P.A.; Wang, S.C.; Baker, J.R., Jr. Topical nano emulsion therapy reduces bacterial wound infection and inflammation after burn injury. Surgery 2010, 148, 499-509. [CrossRef] [PubMed]

107. Wang, X.F.; Zhang, S.L.; Zhu, L.Y.; Xie, S.Y.; Dong, Z.; Wang, Y.; Zhou, W.Z. Enhancement of antibacterial activity of tilmicosin against Staphylococcus aureus by solid lipid nanoparticles in vitro and in vivo. Vet. J. 2012, 191, 115-120. [CrossRef] [PubMed]

108. Liu, Y.; Lim, J.; Teoh, S.-H. Development of clinically relevant scaffolds for vascularised bone tissue engineering. Biotechnol. Adv. 2013, 31, 688-705. [CrossRef] [PubMed]

109. Ensign, L.M.; Cone, R.; Hanes, J. Oral drug delivery with polymeric nanoparticles: The gastrointestinal mucus barrier. Adv. Drug Deliv. Rev. 2012, 64, 557-570. [CrossRef] [PubMed]

110. Tessmar, J.K.; Göpferich, A.M. Matrices and scaffolds for protein delivery in tissue engineering. Adv. Drug Deliv. Rev. 2007, 59, 274-291. [CrossRef] [PubMed]

111. Muñoz-Bonilla, A.; Fernández-García, M. Polymeric materials with antimicrobial activity. Prog. Polym. Sci. 2012, 37, 281-339. [CrossRef]

112. Peng, L.; De Sousa, J.; Su, Z.; Novak, B.M.; Nevzorov, A.A.; Garland, E.R. Inhibition of Acinetobacter baumannii biofilm formation on a methacrylate polymer containing a 2-aminoimidazole subunit. Chem. Commun. 2011, 47, 4896-4898. [CrossRef] [PubMed]

113. Cheow, W.S.; Chang, M.W.; Hadinoto, K. The roles of lipid in antibiofilm efficacy of lipid-polymer hybrid nanoparticles encapsulating antibiotics. Colloids Surf. A 2011, 389, 158-165. [CrossRef]

114. Li, Y.; Fukushima, K.; Coady, D.J.; Engler, A.C.; Liu, S.; Huang, Y.; Cho, J.S.; Guo, Y.; Miller, L.S.; Tan, J.P.; et al. Broad- spectrum antimicrobial and biofilm-disrupting hydrogels: Stereo-Complex driven supramolecular assemblies. Angew. Chem. Int. Ed. Engl. 2013, 52, 674-678. [CrossRef] [PubMed]

115. Liu, R.; Chen, X.; Falk, S.P.; Masters, K.S.; Weisblum, B.; Gellman, S.H. Nylon-3-polymers active against drug-resistant Candida albicans biofilms. J. Am. Chem. Soc. 2015, 137, 2183-2186. [CrossRef] [PubMed]

116. Ghosh, S.; Patil, S.; Ahire, M.; Kitture, R.; Kale, S.; Pardesi, K.; Cameotra, S.S.; Bellare, J.; Dhavale, D.D.; Jabgunde, A.; et al. Synthesis of silver nanoparticles using Dioscorea bulbifera tuber extract and evaluation of its synergistic potential in combination with antimicrobial agents. Int. J. Nanomed. 2012, 7, 483-496.

117. Singh, R.; Nawale, L.; Arkile, M.; Shedbalkar, U.U.; Wadhwani, S.A.; Sarkar, D.; Chopade, B.A. Chemical and biological metal nanoparticles as antimycobacterial agents: A comparative study. Int. J. Antimicrob. Agents 2015, 46, 183-188. [CrossRef] [PubMed]

118. Abdeen, S.; Geo, S.; SukanyaPraseetha, P.K.; Dhanya, R.P. Biosynthesis of silver nanoparticles from Actinomycetes for therapeutic applications. Int. J. Nano Dimens. 2014, 5, 155-162.

119. Chernousova, S.; Epple, M. Silver as antibacterial agent: Ion, nanoparticle, and metal. Angew. Chem. Int. Ed. 2013, 52, 1636-1653. [CrossRef] [PubMed]

120. Ip, M.; Lui, S.L.; Poon, V.K.; Lung, I.; Burd, A. Antimicrobial activities of silver dressings: An in vitro comparison. J. Med. Microbiol. 2006, 55, 59-63. [CrossRef] [PubMed]

121. Jain, P.; Pradeep, T. Potential of silver nanoparticle-coated polyurethane foam as an antibacterial water filter. Biotechnol. Bioeng. 2005, 90, 59-63. [CrossRef] [PubMed]

122. Pallavicini, P.; Taglietti, A.; Dacarro, G.; Diaz-Fernandez, Y.A.; Galli, M.; Grisoli, P.; Patrini, M.; De Magistris, G.S.; Zanoni, R. Self-Assembled monolayers of silver nanoparticles firmly grafted on glass surfaces: Low $\mathrm{Ag}^{+}$release for an efficient antibacterial activity. J. Colloid Interface Sci. 2010, 350, 110-116. [CrossRef] [PubMed]

123. Wadhwani, S.A.; Shedbalkar, U.U.; Singh, R.; Karve, M.S.; Chopade, B.A. Novel polyhedral gold nanoparticles: Green synthesis, optimization and characterization by environmental isolate of Acinetobacter sp. SW30. World J. Microbiol. Biotechnol. 2014, 30, 2723-2731. [CrossRef] [PubMed]

124. Bindhu, M.R.; Umadevi, M. Antibacterial activities of green synthesized gold nanoparticles. Mater. Lett. 2014, 120, 122-125. [CrossRef] 
125. Cui, Y.; Zhao, Y.; Tian, Y.; Zhang, W.; Lu, X.; Jiang, X. The molecular mechanism of action of bactericidal gold nanoparticles on Escherichia coli. Biomaterials 2012, 33, 2327-2333. [CrossRef] [PubMed]

126. Rana, S.; Bajaj, A.; Mout, R.; Rotello, V.M. Monolayer coated gold nanoparticles for delivery applications. Adv. Drug Deliv. Rev. 2012, 64, 200-216. [CrossRef] [PubMed]

127. Vigderman, L.; Zubarev, E.R. Therapeutic platforms based on gold nanoparticles and their covalent conjugates with drug molecules. Adv. Drug Deliv. Rev. 2013, 65, 663-676. [CrossRef] [PubMed]

128. Zhou, Y.; Kong, Y.; Kundu, S.; Cirillo, J.D.; Liang, H. Antibacterial activities of gold and silver nanoparticles against Escherichia coli and bacillus Calmette-Guerin. J. Nanobiotechnol. 2012, 10, 19. [CrossRef] [PubMed]

129. Fang, F.C. Perspectives series: Host/pathogen interactions. Mechanisms of nitric oxide-related antimicrobial activity. J. Clin. Investig. 1997, 99, 2818-2825. [CrossRef] [PubMed]

130. Cochis, A.; Azzimonti, B.; Della Valle, C.; de Giglio, E.; Bloise, N.; Visai, L.; Cometa, S.; Rimondini, L.; Chiesa, R. The effect of silver or gallium doped titanium against the multidrug resistant Acinetobacter baumannii. Biomaterials 2016, 80, 80-95. [CrossRef] [PubMed]

131. Si, X.; Quan, X.; Li, Q.; Wu, Y. Effects of D-amino acids and norspermidine on the disassembly of large, old-aged microbial aggregates. Water Res. 2014, 54, 247-253. [CrossRef] [PubMed]

132. Xu, H.; Liu, Y. D-Amino acid mitigated membrane biofouling and promoted biofilm detachment. J. Membr. Sci. 2011, 376, 266-274. [CrossRef]

133. Lin, N.T.; Chiou, P.Y.; Chang, K.C.; Chen, L.K.; Lai, M.J. Isolation and characterization of phi AB2: A novel bacteriophage of Acinetobacter baumannii. Res. Microbiol. 2010, 161, 308-314. [CrossRef] [PubMed]

134. Li, W.R.; Xie, X.B.; Shi, Q.S.; Duan, S.S.; Ouyang, Y.S.; Chen, Y.B. Antibacterial effect of silver nanoparticles on Staphylococcus aureus. Biometals 2011, 24, 135-141. [CrossRef] [PubMed]

135. Kumar, A.; Kumar-Vemula, P.; Ajayan, P.M.; John, G. Silver nanoparticle embedded antimicrobial paints based on vegetable oil. Nat. Mater. 2008, 7, 236-241. [CrossRef] [PubMed]

136. Braydich-Stolle, L.; Hussain, S.; Schlager, J.J.; Hofmann, M.C. In vitro cytotoxicity of nanoparticles in mammalian germ-line stem cells. Toxicol. Sci. 2005, 88, 412-419. [CrossRef] [PubMed]

137. Graves, J.L., Jr.; Tajkarimi, M.; Cunningham, Q.; Campbell, A.; Nonga, H.; Harrison, S.H.; Barrick, J.E. Rapid evolution of silver nanoparticle resistance in Escherichia coli. Front. Genet. 2015, 6, 42. [CrossRef] [PubMed]

(C) 2016 by the authors; licensee MDPI, Basel, Switzerland. This article is an open access article distributed under the terms and conditions of the Creative Commons Attribution (CC-BY) license (http://creativecommons.org/licenses/by/4.0/). 